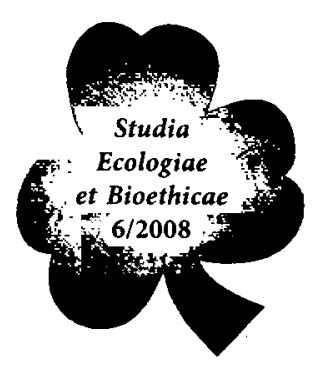

\title{
Krytyka nauki w filozofii Johna Polkinghorne'a
}

\section{Wstęp}

John Polkinhorne - fizyk i duchowny anglikański. W Polsce mniej znany autor, a wydaje się, zasługujący na uwagę dzięki specyficznemu spojrzeniu na naukę i jej rolę w poznawaniu świata. Zanim przyjął święcenia kapłańskie był znanym fizykiem - teoretykiem, specjalistą od cząstek elementarnych i teorii pól kwantowych.

Obecnie często sięga po pióro, by - łącząc głęboką znajomość współczesnej fizyki z nowozdobytą wiedzą teologiczną - dzielić się z czytelnikami osobistym doświadczeniem i przemyśleniami. Są to typowe rozważania „z pogranicza”, w tym wypadku $z$ pogranicza teologii i nauk przyrodniczych. W swoich rozważaniach nawiązuje zarówno do twórców współczesnego przyrodoznawstwa, jak i do filozofów i teologów. W ten sposób staje się orędownikiem holistycznego spojrzenia na świat. Choć nauka dostarcza nam wielu faktów pozwalających coraz lepiej rozumieć otaczającą nas rzeczywistość, to jednak nie wyczerpują one całego jej bogactwa. Potoczne obcowanie ze światem każe nam dostrzec także takie jego wartości jak: piękno, dobro, poczucie moralnego obowiązku. Dopiero próba scalenia obrazów świata dostarczanych przez wieloaspektowe poznawanie staje się prawdziwym przyczynkiem do budowania obiektywnego obrazu świata, w którym żyjemy. Jako duchowny Polkinghorne wielkie znaczenie przypisuje religijnej wizji świata, która umożliwia doświadczenie transcendencji.

\section{Walor poznawczy nauki}

Wkład nauki, rozumianej tu jako przyrodoznawstwo, w coraz głębsze poznanie kosmosu jest niekwestionowany. Próbując nieco uściślić tę z pozoru trywialną tezę Polkinghorne formułuje pięć cech świata, które można mu przypisać na podstawie osiągnięć nauk przyrodniczych'1.

Jako pierwszą cechę wymienia jego poznawalność. Tak bardzo jesteśmy oswojeni $\mathrm{z}$ tą prawdą, że na co dzień nie pamiętamy, że jest to równocześnie fundamentalne

1 J. Polkinghorne, Istnienie świata, tł. M. Iwińska, A. Jancewicz, IW PAX, Warszawa 1988, s. 18. 
założenie czyniące sensownym jakiekolwiek przyrodoznawstwo. Szczególną postacią tej cechy świata jest to, co kryje się pod określeniem matematyzacji przyrody. Matematyka stanowi adekwatny język pozwalający na komunikowanie się ze światem. Fascynujące wydaje się to, że nauka posługując się językiem matematyki potrafi udzielić satysfakcjonujących odpowiedzi na zadawane przez siebie pytania ${ }^{2}$. To zaś utwierdza człowieka w przekonaniu, że nauka zgłębia istotę rzeczywistości. Nie znaczy to, że nauka nigdy nie zachodzi w ślepe zaułki, że nie błądzi. Wręcz przeciwnie, do istoty naukowych procedur należy błądzenie, szukanie, cofanie się i zaczynanie od nowa ${ }^{3}$. Badania $z$ dziedziny współczesnej fizyki, w szczególności badania prowadzone w mikroświecie, skłaniają naukowców do sformułowania wniosku, iż jedynym wręcz kryterium rzeczywistości jest jej zrozumiałośćt.

Drugą cechą świata wymienianą przez Polkinghorne’a na podstawie osiągnięć nauk empirycznych jest jego równoczesna przypadkowość i konieczność. Dzięki przypadkowi powstaje coś nowego, zaś stałe prawa natury powodują, że to nowe nie ginie ale zostaje zachowane w środowisku. Istnienie przypadkowości i konieczności zarazem w otaczającym nas świecie stanowi dla wielu dowód na jego bezsens i pust$\mathrm{kęq}^{5}$. Dla Polkinhorne’a jest to "dowód" na działanie w świecie czynnika celowościowego. Zstrzega, iż nie jest to dowód na istnienie Pana Boga, gdyż takie dowody nie istnieją, ale przyjęcie takiego czynnika stanowi wielką pomoc w zrozumieniu świata ${ }^{6}$. Analizując sytuację, w której te same fakty naukowe wywołują krańcowo odmienne interpretacje w umysłach naukowców, jak w przypadku Monoda.i swoim własnym, Polkinghorne sugeruje, iż źródło takiej sytuacji tkwi poza ściśle naukowym obrazem świata.

Trzecia cecha świata wymieniana przez Polkinghorne’a na podstawie danych pochodzących $z$ naukowego jego obrazu związana jest $\mathrm{z}$ powszechnie dziś akceptowanym poglądem na powstanie świata, zwanym „Wielkim Wybuchem”. Uwagę Polkinghornea zwraca przede wszystkim fakt konieczności zaistnienia w początkowej fazie Wszechświata delikatnej i złożonej równowagi jego struktur, koniecznej dla powstania życia w formie przez nas dziś obserwowanej. Każda, nawet drobna zmiana, w proporcjach parametrów opisujących stan Wszechświata w jego pierwszych sekundach istnienia uniemożliwiłaby powstanie życia ${ }^{7}$. Ten zastanawiający fakt został zinterpretowany $i$ opisany $w$ tzw. zasadzie antropicznej. Zasada antropiczna stanowi przykład przenikania elementów humanistyczno-personalistycznych do nauk przyrodniczych. W swej najogólniejszej postaci mówi, że obserwowany przez nas

2 J. Polkinghorne, Poza nauką, Amber, Warszawa 1998, s. 13.

3 Por. T.S. Kunn, Dwa bieguny, PIW, Warszawa 1985; oraz K.R. Popper, Wiedza obiektywna, PWN, Warszawa 1992.

4 Por. E. Mascall, Teologia chrześcijańska a nauki przyrodnicze, IW PAX, Warszawa 1968, s. 28.

5 Por. np. J. Monod, Przypadek i konieczność, Biblioteka Głosu, Warszawa 1996.

6 J. Polkinghorne, Istnienie świata, ..., s. 21.

7 Por. C.B. Collins, S.W. Hawking, Why is the Universe Isotropic?, Astrophysical Journal (1973)180, s. 317-334. 
świat jest taki, jaki jest, ponieważ istnieje człowiek. Zasada antropiczna nie stanowi jakiegoś nowego, fundamentalnego prawa fizyki. Jest raczej sposobem rozumowania, w którym $\mathrm{z}$ faktu istnienia człowieka na jednej z planet wnioskuje się coś o Wszechświecie jako całości.

Czwarta cecha świata przywoływana przez Polkinhorne’a jest przez niego samego oceniana jako, z pozoru, naiwna. Otóż jako godny zastanowienia się nad nim fakt Polkinkhorne uznaje nieograniczoność świata, jego wielkość. Powołuje się przy tym zarówno na teksty wcześniejszych filozofów, jak i na Pismo Święte ${ }^{8}$. To zainteresowanie się „wielkością świata” ma swoje korzenie we wspomnianej wcześniej zasadzie antropicznej. Według niej świat musi być tak wielki, by mogło zaistnieć na nim życie. Polkinhorne uważa ten fakt za bardzo inspirujący filozoficznie?.

Ostatnia, piąta cecha Wszechświata jaka wynika $z$ dostarczanego nam przez nauki szczegółowe jego obrazu, to samowystarczalność. Dla Newtona i jego współczesnych świat wydawał się być zagrożonym przez zakłócenia powodowane przez wzajemne oddziaływanie na siebie sąsiednich planet. Jedynym rozsądnym wytłumaczeniem faktu, iż świat nie podlega destrukcji wydawało się włączenie $w$ ten naukowy obraz świata wykreowany przez jego fizykę, hipotezy Boga. To Bóg posługując się siłami anielskimi sprawia, że system słoneczny „trzyma się w posadach”. Późniejszy postęp w naukach fizycznych dowiódl, że w istocie rzeczy owe zaburzenia wykazują skłonność do wzajemnego znoszenia się, że cały system jakim jest otaczający nas świat, ze swej natury jest stabilny.

Opisany przez naukę i ujęty przez Polkinhorne’a w pięciu cechach Wszechświat jawi się jako samowystarczalny, samotłumaczący się. Czy jest tak jednak rzeczywiście? - zastanawia się Polkinghorne. Jego odpowiedź jest negatywna. Nie cała rzeczywistość świata daje się wyczerpać a nawet opisać w kategoriach nauk przyrodniczych. Za integralną część doświadczeń naukowca Polkinghorne uważa zachwyt nad strukturą świata. Na ten zachwyt nie ma miejsca w naukowym tylko opisie świata. Nie tylko zachwyt wymyka się naukowym opisom ale także dobro, piękno czy obowiązek. Te wymykające się naukowym dywagacjom doświadczenia, to nie tylko „pozbawione znaczenia zmarszczki na powierzchni mechanicznie rozwijającego się świata"10 - pisze Polkinghorne ale mają one istotne znaczenia dla jego zrozumienia

\section{Niewystarczalność przyrodoznawstwa w poznaniu świata}

Kluczową rolę w tworzeniu nauki i w procesie jej rozwoju odgrywa człowiek. Przyjmowana koncepcja nauki wpływa na określenie miejsca jakie człowiek zajmuje w świecie przyrody ale także czlowiek oddziałuje na wyniki poznania naukowego. Zarówno epoka nowożytna jak i współczesność proponują pewną określoną wizję

8 Por. np. B. Pascal, Myśli, IW PAX, Warszawa 1975; a także Ps 8, 4-5 Biblia Tysiąclecia, Pallotinum, Poznań 2003.

9 J. Polkinkghorne, Istnienie świata,..., , s. 22.

10 J. Polkinghorne, Istnienie świata... , s. 26. 
nauki. Wydaje się, iż każda $z$ nich wywiera istotny, a zarazem różny wpływ na relacje zachodzące między człowiekiem a przyrodą.

Towarzysząca nauce doby pozytywizmu euforia, wyrażająca się w przekonaniu o nieograniczonych możliwościach nauki w procesie poznawania świata, dzisiaj osłabła, ustępując miejsca rodzącym się rozczarowaniom ze względu na konsekwencje, którymi się naukę obciąża. Do takich negatywnych następstw uprawiania nauki zalicza się choćby konstruowanie coraz doskonalszej i skuteczniejszej broni czy obserwowane powszechnie zanieczyszczenie środowiska.

Dynamiczny rozwój nauk przyrodniczych, jaki rozpoczął się wraz z epoką nowożytną, miał doprowadzić człowieka do pełnej wiedzy o wszystkim. Gwarantować miał to ciąghy, linearny proces rozwoju nauki wykorzystującej eksperyment jako swoją fundamentalną i jedyną metodę. Sprowadzenie jednak całej rzeczywistości do obszaru będącego przedmiotem eksperymentalnych nauk przyrodniczych stało się najpierw powodem uprzedmiotowienia przyrody, potem uprzedmiotowienia samego człowieka, a w efekcie końcowym, powodem kryzysu ekologicznego.

Człowiek, jako jedyna istota $w$ otaczającym nas i będącym przedmiotem badań wszechświecie, jawi się jako posiadająca zainteresowania intelektualne ${ }^{11}$. Od samego początku w człowieku kształtowały się wraz z dążnością do wytłumaczenia świata, zainteresowania estetyczne, religijne i metafizyczne. Świadectwem tego są znajdowane w grotach sprzed dziesiątek tysięcy lat malowidła będące znakami bądź to zachowań altruistycznych, bądź wiary w dalsze życie po śmierci. Kolebką naszej cywilizacji jest Grecja. To właśnie tam twórcy filozofii a więc ci, którzy kładli podwaliny pod współczesną naukę zastanawiali się zarówno nad pięknem poematów Homera jak i nad istotą prazasady wszechrzeczy - arche. Rozważali zagadnienia dotyczące moralności jaki i geometrii Wszechświata. Warto zauważyć, że tego typu rozważania nie przynosiły wymiernych korzyści w walce o byt. Wskazują one jednak na coś innego, mianowicie na to, że środowiskiem naturalnym człowieka jest świat idei, sensu i prawdy. Takie widzenie środowiska człowieka miało i ma oponentów. Przedstawianie społeczeństwa, w którym ludzie wolni są od pasji i zainteresowań intelektualnych miało miejsce w starożytności i w świecie nowożytnym. Można także wiele z tych opisów znaleźć w otaczającym nas świecie opisywanym dziś przez twórców postmodernistycznych. Pozostaje bardzo ważne pytanie: jak wyglądałaby i czy w ogóle jest możliwa kultura naszego gatunku pozbawiona wątku sensu i tajemnicy? Gdyby naszego horyzontu poznawczego nie określały intelektualne pasje i dążenie do duchowej doskonałości?

Od stanu początkowej osobliwości Wszechświata upłynęło ok. 13,7 miliardów lat. Tak wynika $z$ najnowszych opracowań przyrodoznawczych ${ }^{12}$. Nasz gatunek Homo sapiens sapiens liczy sobie dopiero ok. 100 tysięcy lat. Gdyby nawet nie były to calkiem dokładne ustalenia czasowe, to mimo wszystko egzystencja człowieka stanowi

"I. ŻYcıŃsKi, Wspólnota wartości i sensu, Alma Mater 2(2007), s. 41.

12 Tamże, s. 42. 
zaledwie 0,00073 \% wieku obecnej formy Wszechświata. Zatem ponad 99,99\% swej historii Wszechświat rozwijał się bez człowieka. Można na podstawie tych faktów postawić hipotezę, że późno pojawiający się na Ziemi człowiek zniknie z jej powierzchni bardzo szybko. Mówi się wtedy o czekającej świat erze posthumanizmu. Jest to wizja bardzo pesymistyczna. Skądinąd wiadomo przecież, że do zaistnienia życia $w$ takiej formie, $w$ jakiej ono dzisiaj występuje na Ziemi potrzebny był rozległy i stary Wszechświat. O naszej zaś przyszłości najbardziej zdają się decydować działania wyrażające odpowiedzialność człowieka za kulturę.

\section{Próba holistycznego ujęcia rzeczywistości w filozofii Johna Polkinghorne'a}

U podstaw dążenia do pełnej prawdy o Wszechświecie leży zasada respektowania autonomii poszczególnych dyscyplin naukowych. Konieczne jest także uwzględnianie różnic języków i metod badawczych. Wydaje się też być oczywistym, że istnieją istotne sfery ludzkiej kultury i ludzkiego życia, które są niepoznawalne przy użyciu metod właściwych naukom przyrodniczym.

Jako najbardziej fascynujące w nauce Polkinghorne postrzega to, że potrafi ona udzielić satysfakcjonujących odpowiedzi na zadawane przez siebie pytania ${ }^{13}$. Ten fakt sprawia, że nauka stanowi dla większości formę prawdziwego poznania. Taka zaś koncepcja nauki może sugerować, iż jest ona narzędziem, za pomocą którego człowiek w prosty sposób osiągnie pełną wiedzę o wszechświecie. Uprawianie nauki zapewni człowiekowi poznanie wszystkich tajemnic otaczającej go rzeczywistości. Poznanie to dokonuje się w skończonym czasie, ponieważ nauka osiągnie kiedyś swój cel wyjaśniając wszystko. Stanie się tak dlatego, że proces rozwoju nauki wydaje się ciągły, nie zakłócany w żaden sposób i konsekwentnie zmierzający do poznania prawdy. Kumulatywna teoria nauki przyczynia się do tego, że człowiek zajmuje pozycję absolutnie nadrzędną w stosunku do przyrody. Wiedza jaką człowiek zdobywa dzięki uprawianej nauce jest absolutną prawdą i pozwala mu mniemać o swej wręcz boskiej władzy nad światem przyrody. Przekonanie o tak szczególnym miejscu człowieka w świecie przyrody stało się powodem zaistnienia dualizmu człowiek podmiotem, przyroda - przedmiotem poznania naukowego. Dualizm ten utrwalała i pogłębiała rola i znaczenie eksperymentu naukowego. W koncepcji nauki nowożytnej, która zrodziła kumulatywizm, eksperyment stanowil jedyne i zarazem najdoskonalsze narzędzie badania rzeczywistości. W mentalności ludzkiej wytworzyło się przekonania o tym, że jeśli przyroda jest tylko biernym przedmiotem poznającej i działającej podmiotowości ludzkiej, to nie ma powodów, z racji których czlowiek nie miałby dowolnie nią rozporządzać i jej wykorzystywać.

Taka jednak postawa, zdaniem Polkinghorne'a prowadzi wprost do zafałszowania obrazu świata ponieważ rozmyślnie ignoruje niemal wszystko, co nadaje życiu

13 J. Polkinghorne, Poza naukq..., s. 13. 
wartośćc ${ }^{14}$. Ta pełna uwielbienia dla nauki postawa nie jest jedyną spotykaną dziś w kręgach naukowców. Jej przeciwieństwem jest postawa, która wyraża sympatię ku destruktywnemu obrazowi nauki. Można wyróżnić tu dwa warianty takiej postawy. Pierwszy to popularystyczne (dziennikarskie) wyolbrzymianie faktu, że nauce, jak dotąd, nie udało się zaspokoić ludzkich potrzeb. Drugi, to filozoficzna krytyka twierdzenia, iż tylko nauka jest w stanie dostarczyć wiedzy. Pierwszy wariant akcentuje tzw. imperializm naukowy przejawiający się $\mathbf{w}$ depersonalizacji rzeczywistości i odrzucaniu wszelkiej wartości. Takie poczynania są zgubne dla człowieka.

Drugi wariant opiera się na filozoficznym przekonaniu, iż twierdzenie, że precyzyjne przewidywanie teoretyczne uzyskuje niepodważalne potwierdzenie doświadczalne i w ten sposób dochodzi się do określonej prawdy jest niesłychanym uproszczeniem. Niestety należy liczyć się $\mathrm{z}$ wieloma względami, które komplikują sprawę ${ }^{15}$.

Po pierwsze wydaje się być niemożliwym zachowanie jednoznacznego podziału na teorię i doświadczenie. Prowadzi to do sytuacji, w której porównanie jednego $z$ drugim okazuje się niemożliwe. $W$ procesie naukowego zdobywania wiedzy teoria i eksperyment są ze sobą nierozerwalnie splecione. Wszelka obserwacja naukowa jest zawsze „widzeniem jako". Znaczy to, że nasze pytania stawiane pod adresem rzeczywistości nas otaczającej zadajemy zawsze $\mathrm{z}$ jakiegoś wybranego punktu widzenia. Konieczność przyjęcia w badaniach naukowych jakiegoś punktu widzenia niesie ze sobą element ryzyka.

Po drugie należy zdać sobie sprawę $z$ tego, że choć teoria jest w nauce niezbędna, to dane określają ją zawsze niedostatecznie. Szczególnym przejawem tego typu trudności jest problem wnioskowania indukcyjnego, które stanowi naczelną metodę postępowania $w$ naukach przyrodniczych. Jedną $\mathrm{z}$ postaci tego zagadnienia jest pytanie o to, dlaczego doświadczenia z przeszłości mają być wskazówką odnośnie zachowań $\mathrm{w}$ przyszłości?

I wreszcie po trzecie, to ograniczenia jakie niesie ze sobą nasze poznanie świata. Jest ono ze swej natury niejednoznaczne. Na przestrzeni dziejów nauk przyrodniczych właśnie to ograniczenia było powodem żenujących przypadków wyciągnięcia całkowicie fałszywych wniosków $z$ konkretnych faktów.

Zarówno epoka nowożytna jak i współczesność proponują pewną określoną wizję nauki. Wydaje się, iż każda $\mathrm{z}$ nich akcentuje jakiś aspekt rzeczywistości i dopiero ich wypadkowa zdaje się prowadzić ku prawdzie o Wszechświecie.

Trwające w epoce Galileusza dyskusje dotyczące tego, czy świat jest lepiej opisywany przez model maszyny czy też organizmu zakończyła era pozytywizmu opowiadając się za modelem maszyny. Dziewiętnasty wiek sprecyzował wobec rozwijającej się biologii swe pytania odnośnie tego modelu. Chodziło mianowicie o to, jakiemu typowi maszyny odpowiadają struktury przyrody ożywionej, w tym także człowie$\mathrm{k}^{16}$. Możliwe są dwa warianty. Pierwszy, w którym przyroda jest maszyną funkcjo-

14 Tamże, s. 13.

15 Tamże, s. 15. 
nującą wyłącznie w oparciu o uwarunkowania przyczynowe i drugi uwzględniający także czynniki celowościowe. Ten drugi wariant zakłada istnienie i działanie w świecie Boga ukierunkowującego funkcje poszczególnych elementów przyrody. Istotny wpływ na większą popularność pierwszego $z$ sygnalizowanych wariantów, czyli ujmowania przyrody jako przyczynowo uwarunkowanej maszyny, wywarła darwinowska teoria doboru naturalnego. Sugerowała ona bowiem koncepcję wszechświata, w którym obowiązują determinizm i prawo walki o byt ${ }^{17}$.

Koncepcja ta staje w opozycji do dawnej, celowościowej wizji wszechświata, w którym panuje harmonia i ład, gatunki są niezmienne a wszystkie procesy przebiegają zgodnie $\mathrm{z}$ początkowym planem określonym przez Stwórcę. W takiej wizji doskonałego ładu i harmonii swoje określone miejsce zajmował także człowiek. W tak zwanym wielkim łańcuchu bytów najniższe ogniwo stanowiły robaki, najwyższe zaś aniołowie. Pośrednie poziomy zajmowały inne istoty, tworząc $w$ ten sposób przejrzysty i uporządkowany obraz przyrody o bardzo stabilnym charakterze ${ }^{18}$.

Wraz z rodzącym się ewolucjonizmem miejsce uporządkowanego łańcucha bytów zajęła wizja świata, w' którym poszczególne istoty, także człowiek, muszą walczyć o przetrwanie. Łączące czlowieka ze światem przyrody relacje harmonijnego współistnienia musiały ustąpić miejsca wiecznemu antagonizmowi. Pytanie jakie w tym kontekście stawiano, dotyczyło tego, czy wyniki tej walki dają się ściśle przewidzieć, czy też decydującą rolę w rozwoju przyrody odgrywa przypadek i chaos. Zdecydowanie przeciwko chaosowi opowiadał się T.H. Huxley utrzymując, że tak zwany przypadek jest jedynie przejawem działania nieznanych jeszcze sił ${ }^{19}$. Znajomość początkowych warunków ewolucji i jej praw pozwoliłaby jednoznacznie określić wszystkie zdarzenia składające się na historię wszechświata. Także człowiek zachowuje się według zasad ściśle określonych prawami mechaniki.

Obserwowane w dobie pozytywizmu sukcesy nowożytnej nauki przyczynily się do przemiany świadomości człowieka będącego bezpośrednim sprawcą tychże dokonań. Ta przemiana polegała przede wszystkim na nowym samookreśleniu się człowieka jako tego, który dzięki nauce poznaje wprost i ostatecznie wszystkie tajemnice przyrody. Niewątpliwie wpływ na ową przemianę miała rewolucja przemysłowa akcentując znaczenie ludzkiej pracy i jej twórczej roli. Później jednak dostrzeżono także negatywne skutki ludzkiej działalności, które zwykło się określać mianem degradacji naturalnego środowiska życia ludzkiego ${ }^{20}$.

16 M. Heller., J. Życiśski, Wszechświat - maszyna czy myśl?, Polskie Towarzystwo Teologiczne, Kraków 1988, s. 173

17 Por. S.J. Gould, Niewczesny pogrzeb Darwina, PIW, Warszawa 1991.

18 A.O. Lovejoy, The Great Chain of Being, Cambridge 1936.

19 T.H. HuXLEY, Collected Essays, London 1894.

20 M. LuBAŃski, B. HAŁACZEK, Filozoficzne aspekty ekologii, Chrześcijanin a współczesność (1988)5, s. 11-17. 
Mechanistyczny obraz świata i związany z nim wyraźny podział na podmiot i przedmiot w poznaniu naukowym stał się przyczyną wielu nadużyć popełnianych przez człowieka względem przyrody. Nauka uprawiana w konwencji scjentystyczno-mechanistycznej zorientowana była na świat radykalnie zewnętrzny względem człowieka. Przyroda opisywana przez naukę za pomocą konstrukcji teoretycznych była jedynie przedmiotem badań w pełni od człowieka uzależnionym. Ów ostry podział na ludzką podmiotowość i przedmiotowość świata zewnętrznego zapewne warunkował powstanie i przyspieszał rozwój nauk przyrodniczych. $Z$ drugiej jednak strony można przypuszczać, że właśnie ten podział stał się powodem rabunkowej gospodarki przyrodą i przyczyną obserwowanego kryzysu ekologicznego ${ }^{21}$. Choć w literaturze analizującej problem kryzysu ekologicznego wskazuje się na różne jego przyczyny, to jednak jako najistotniejszą wymienia się dualizm: człowiek-podmiotem; przyroda-przedmiotem działalności naukowej. Zauważa to także J. Polkinhorne w swym dziele Science and Creation ${ }^{22}$.

Obok ostrego podziału na podmiot i przedmiot poznania, funkcjonowała w obrębie pozytywistycznie rozumianej nauki, jeszcze jedna zasada o istotnym znaczeniu. Chodziło w niej o to, aby za poznawalne uznawać wszystko to i tylko to, co jest stwierdzalne w eksperymencie, a zatem co jest przewidywalne i wykonalne. Zasada ta, podobnie jak dualizm podmiot-przedmiot, skłaniała i wręcz zachęcała człowieka do niczym nie ograniczonej swobody działania. Stawiała bowiem znak równości pomiędzy obiektywną poznawalnością zjawisk a ich przewidywalnością, pomiędzy powtarzalnością a reprodukowalnością. Sprawiło to, że wykonywalność, czyli sama możliwość sprawczego działania zdobyła rangę podstawowego i w pełni wystarczającego kryterium tegoż działania ${ }^{23}$. W praktyce oznaczało to, że wszystkie stwarzane przez naukę i technikę możliwości działania powinny być realizowane. Tak też faktycznie się działo nawet przy oczywistej niemożności przewidzenia wszystkich skutków określonego działania. Sama na przykład możliwość genetycznych czy farmakologicznych ingerencji człowieka w jego własne i otaczające go życie stała się wystarczającym bodźcem do ich realizacji. Podejmowanie takich czynności przy znacznym stopniu niewiedzy dotyczącej pełnej znajomości następstw może prowadzić i w wielu przypadkach prowadzi do szkód obarczających zarówno samego człowieka jak i otaczającą go przyrodę ${ }^{24}$.

W przeciwienstwie do mechanistycznego widzenia świata czasów nowożytnych wyłania się ze współczesnych nauk fizykalnych światopogląd, który można określić jako organiczny. W pewnym sensie nawiązuje on do tradycji starożytnej i średniowiecznej. Wszechświat przestaje w nim być maszyną, składającą się z szeregu nieza-

21 B. HA£ACZEK, Nauka w poszukiwaniu etyki, Collectanea Theologica (1988)58, s. 42-50

22 Por. J. Polkinghorne, Science and Creation, Templeton Foundation Press, Philadelphia London 1989.

23 J. Bogusz, Etyczne granice eksperymentu klinicznego, Studia Philosophiae Christianae (1988)2, s. 165-177.

24 B. HaŁACzeK, Nauka w poszukiwaniu etyki.., s. 44. 
leżnych od siebie elementów, a postrzegany jest jako jedna, niepodzielna, dynamiczna całość. Poszczególne części tej całości, także człowiek, są od siebie nawzajem zależne i mogą być zrozumiałe tylko na tle prawidłowości całego procesu kosmicznego ${ }^{25}$.

Wypływająca ze współczesnej koncepcji nauki wizja rzeczywistości bazuje na uznaniu zasadniczych powiązań i zależności łączących wszystkie zjawiska - fizyczne, biologiczne, psychiczne, społeczne i kulturowe. Osiągnięcia współczesnych nauk fizykalnych zdają się przełamywać pozytywistyczny podział na podmiot i przedmiot poznania. Człowiek nie jest już wyłącznie panem przyrody ale jest zarazem jej integralną częścią. Chociaż bowiem wpływa na przebieg zachodzących procesów fizycznych (wynika to choćby $z$ teorii nieoznaczoności Heisenberga ), to przecież te $z$ kolei kształtują środowisko, w którym żyje.

Nauka współczesna odebrała człowiekowi wiarę w możliwość przewidywania wszystkiego za pomocą naukowego badania świata. Pozytywistyczna wizja nauki jako absolutnie pewnego narzędzia w poznawaniu prawdy okazała się być błędną. Od momentu narodzin mechaniki kwantowej nie można bowiem mówić o klasycznie rozumianej przyczynowości, gdyż nie w każdym pojedynczym przypadku można odróżnić przyczynę od skutku. Tak na przykład osiągnięcia współczesnej dynamiki czy chemii przypisują losowi i prawdopodobieństwu zasadniczą rolę w dokonujących się procesach świata przyrody ${ }^{26}$.

Nowa wizja nauki zakwestionowała uproszczoną w dobie pozytywizmu relację nauki do prawdy. Metody nauk eksperymentalnych nie prowadzą człowieka wprost do prawdy absolutnej o wszechświecie. Cechą charakterystyczną pojmowanej współcześnie nauki jest błądzenie, szukanie, nieraz cofanie się ${ }^{27}$. Poznanie naukowe jest raczej procesem ciągłego przybliżania się do prawdy.

Zarówno indeterminizm w nauce jak i poddanie w wątpliwość przez Kuhna i Feyerabenda relacji nauki do prawdy przyczyniły się do pojawienia się przekonania o niewystarczalności samych tylko nauk przyrodniczych w tworzeniu opisu świata. W pracach współczesnych przyrodników coraz częściej zaczęły pojawiać się rozważania wychodzące daleko poza zakres ich specjalizacji. Rozważania te nieraz prowadziły do konkluzji, z których wynikała konieczność podporządkowywania możliwości działań stwarzanych przez naukę innym wartościom, np. etycznym ${ }^{28}$. Uświadomienie sobie tego typu ograniczeń w nauce stanowiło także swego rodzaju hamulce nałożone na zapędy nieograniczonych ingerencji człowieka w świat przyrody.

Na tle przeobrażeń jakim została poddana wizja nauki w okresie popozytywistycznym coraz mocniejsza jawiła się potrzeba określenia pozycji człowieka w ota-

${ }^{25}$ Por. M. LuBAŃski, Zagadnienia antropologiczne w aspekcie systemowo-informacyjnym, Roczniki Filozoficzne (1981)29, s. 5-20.

26 Por. I. Prigogine, I.STEngers, $Z$ chaosu $k u$ porzadkowi, PIW, Warszawa 1990.

${ }^{27}$ por. K.R. POPPER, Wiedza obiektywna. Ewolucyjna teoria epistemologiczna, PWN, Warszawa 1992.

28 Por. S.W. Hawking, Czarne dziury i wszechświatay niemowlęce, Alkazar, Warszawa 1993. 
czającej go rzeczywistości. Wizja człowieka jako boga otaczającej go przyrody okazała się nieadekwatna wobec osiągnięć współczesnych nauk przyrodniczych.

Na przestrzeni ostatnich lat pojawiły się w wielu dyscyplinach naukowych koncepcje, które stanowią wyraźny przejaw idei jedności. Znaczenie tych koncepcji oraz stopień ich akceptacji przez profesjonalne środowiska jest różny. Na szczególną uwagę zasługują takie koncepcje, jak: hipoteza bootstrapu; koncepcja ukrytego porządku; koncepcja pola morfogenetycznego; koncepcja struktur dysypatywnych oraz koncepcja pamięci holograficznej. W każdej z nich kryje się odpowiedni obraz otaczającej człowieka rzeczywistości, sugerujący równocześnie określoną relację człowieka do tejże rzeczywistości.

Zdaniem Polkinghorne’a w procesie zgłębiania prawdy o wszechświecie nie do przecenienia jest rola teologii ${ }^{29}$. W trakcie realizacji tego zadania teologia uwzględniać musi wyniki badań innych nauk. Musi to jednak odbywać się bez hegemonicznych roszczeń w stosunku do nich. Łatwo zauważyć jak bardzo tradycyjna problematyka teologiczna może zostać wzbogacona przez sprowadzenie jej do twórczego oddziaływania $\mathrm{z}$ fundamentalnymi osiągnięciami nauk. „Jednym z najpotężniejszych motywów ludzkiego działania - pisze Polkinghorne - jest potrzeba nadania sensu całemu naszemu doświadczeniu, zdobycia spójnego i satysfakcjonującego zrozumienia świata, w którym żyjemy. Właśnie to dążenie jednoczy naukę i teologię we wspólnym zaangażowaniu." ${ }^{30}$

Naukowa działalność człowieka oparta jest na aksjomatycznym założeniu, że świat jest dla człowieka zrozumiały, że da się go badać. Założenie to jest tak głęboko zakorzenione w naszej świadomości, że nie stanowi na codzień przedmiotu głębszej refleksji. Bynajmniej nie jest to jednak założenie trywialne. Świat w opinii Polkinghorne’a mógłby być zupełnie niezorganizowanym chaosem, pod adresem którego nie można by postawić żadnego sensownego pytania. Mogło by być też tak, że struktura Wszechświata wykraczałaby poza wszelkie granice możliwości poznawczych naszego rozumu. Tak jednak nie jest. Nasz umysł zdaje się być dziwnie przystosowany do świata lub może świat do naszego umysłu. ,Jeżeli ta tak głęboko zakorzeniona zgodność racjonalności obecnej w naszych umysłach $\mathrm{z}$ racjonalnością obecną w świecie ma znaleźć prawdziwe wyjaśnienie, bez wątpienia musi ono znajdować się w jakiejś bardzo głębokiej warstwie stanowiącej podstawę obydwu tych dziedzin. Może nią być Racjonalność Stwórcy" ${ }^{31}$. Takie jest "Credo" Polkinghorne’a w sprawie statusu poznawczego nauki i jej związków z teologią.

\footnotetext{
29 Por. J. Polkinghorne, Science and Creation..., s. 74.

30 Tamże, s. 102.

31 Tamże, s. 69.
} 


\section{LITERATURA}

J. Bogusz, Etyczne granice eksperymentu klinicznego, Studia Philosophiae Christianae (1988)2, s. 165 177.

Biblia Tysiąclecia, Pallotinum, Poznań 2003.

C.B.Collins, S.W. Hawking, Why is the Universe Isotropic?, Astrophysical Journal (1973)180, s. 317 334.

S.J.Gould, Niewczesny pogrzeb Darwina, PIW, Warszawa 1991.

B. Ha£ACzeK, Nauka w poszukiwaniu etyki, Collectanea Theologica (1988)58, s. 42-50.

S.W. HaWkInG, Czarne dziury i wszechświatay niemowlęce, Alkazar, Warszawa 1993.

M. Heller, J. ŻyCińsKi, Wszechświat - maszyna czy myśl?, PTT, Kraków 1988.

T.H. HuXLey, Collected Essays, London 1894.

T.S. Kunn, Dwa bieguny, PIW, Warszawa 1985.

A.O. Lovejoy, 1936, The Gread Chain of Being, Cambridge.

M. LUBAŃSKI, Zagadnienia antropologiczne $w$ aspekcie systemowo-informacyjnym, Roczniki Filozoficzne (1981)29, s. 5-20.

M. LUBAŃSKI, B. HAŁACZEK, Filozoficzne aspekty ekologii, Chrześcijanin a wspótczesność (1988)5, s.11-17.

E. MASCALL, Teologia chrześcijańska a nauki przyrodnicze, IW PAX, Warszawa 1968.

J. Monod, Przypadek i konieczność, Biblioteka Głosu, Warszawa 1996.

B. PASCAL, Myśli, IW PAX, Warszawa 1975.

J. Polkinghorne, Istnienie świata, IW PAX, Warszawa 1988.

J. Polkinghorne, Science and Creation, Templeton Foundation Press, Philadelphia - London 1989.

J. Polkinghorne, Poza nauka, Amber, Warszawa 1998.

K.R. PopPeR, Wiedza obiektywna. Ewolucyjna teoria epistemologiczna, PWN, Warszawa 1992.

I.Prigogine, I.STengers, Z chaosu ku porzadkowi, PIW, Warszawa 1990.

J. ŻYcıŃski, Wspólnota wartości i sensu, Alma Mater 2(2007), s. 41. 